\title{
The effect of body mass index on trauma severity and prognosis in trauma patients
}

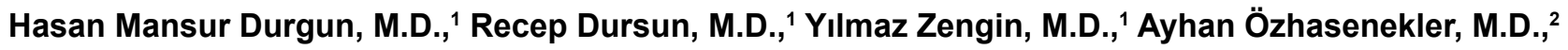 \\ Murat Orak, M.D., ${ }^{1}$ Mehmet Üstündağ, M.D., ${ }^{1}$ Cahfer Güloğlu, M.D. ${ }^{1}$
}

1'Department of Emergency Medicine, Dicle University Faculty of Medicine, Diyarbakır-Turkey

${ }^{2}$ Department of Emergency Medicine, Yildirim Beyazit University Faculty of Medicine, Ankara-Turkey

\begin{abstract}
BACKGROUND: As in the rest of the world, the prevalence of obesity in Turkey has been increasing in recent years and has become a major public health issue. Although many trials have been conducted to study the effects of obesity on internal diseases, there are few studies investigating the effects of obesity on prognosis of trauma patients. The present study analyzed the effects of body mass index (BMI) on trauma severity and prognosis in trauma patients.

METHODS: This study was prospectively conducted with trauma patients older than 15 years of age who presented at the Dicle University Faculty of Medicine emergency medicine department trauma unit between June I, 2013 and May 3I, 20I4. Patients were grouped into high-energy trauma and low-energy trauma groups based on trauma severity. In addition, 4 groups were made according to $\mathrm{BMI}$ value $\left(\mathrm{kg} / \mathrm{m}^{2}\right)$. Group I was defined as BMI <25 (normal weight). Group II patients had BMI of $25-29.9$ (overweight). Group III had BMI of 30-34.9 (obese), and Group IV was made up of patients with BMI $\geq 35$ (morbidly obese).
\end{abstract}

RESULTS: Comparison of whole patient population for inter-group differences showed significant differences between rate of head injury, thoracic injury, extremity injury, multitrauma, clinic admission rate, and mortality rate $(p<0.00 \mathrm{I})$. No significant difference was observed between groups in abdominal injury rate $(p=0.347)$.

CONCLUSION: Clinic admission rate, length of intensive care unit stay, mortality rate, multitrauma rate, and injury severity score increased in proportion to greater BMI.

Keywords: Body mass index; obesity; trauma severity indices.

\section{INTRODUCTION}

The prevalence of obesity has recently increased and become a major public health concern. Obese patients are at especially higher risk for certain disorders such as cancer, hypertension, heart disease, diabetes mellitus (DM), hyperlipidemia, insulin resistance, and arthritis. In addition, they also have higher risk of mortality. ${ }^{[1]}$ Numerous studies have demonstrated the relationship between obesity and the above-mentioned disorders. Obesity is directly or indirectly linked to 7

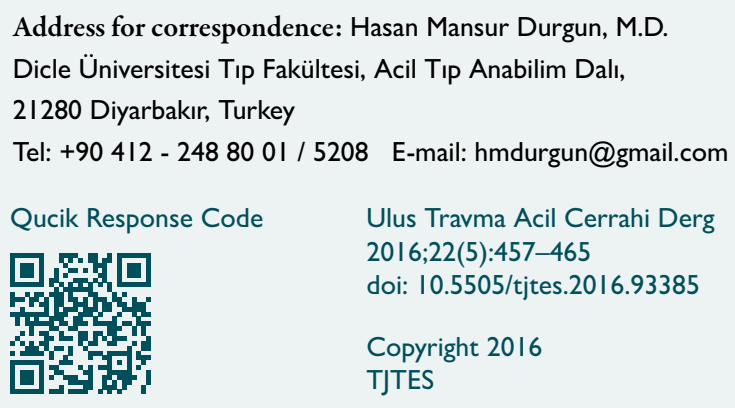

among the 10 most common causes of death (heart disease, malignancy, stroke, chronic obstructive respiratory disease, DM, influenza, and pneumonia). ${ }^{[2,3]}$

Although the association of obesity with various internal disorders has been widely studied, the number of studies investigating the effect of obesity on prognosis of trauma patients is rather limited. Some studies have demonstrated that obesity is an independent risk factor for mortality in highenergy blunt traumas. ${ }^{[4]}$ Obesity has been identified as a risk factor for adverse outcomes after trauma in adult patients, and mortality and morbidity rates, length of hospital stay, and injury severity score (ISS) have been found higher in obese adolescents with traumatic injury compared to their normalweight counterparts. ${ }^{[5,6]}$

The present study investigated whether or not body mass index (BMI) had an incremental effect on trauma severity in trauma patients, and we sought to answer the following questions: (a) Is there any difference between prognosis, clinical admission, need for intensive care, mortality rate, and dura- 
tion of hospital stay between obese or overweight patients and normal-weight patients in high-energy (HET) (e.g., motor vehicle accidents, fall from a height) and low-energy traumas (LET)? (b) Is there a relationship between BMI and ISS score?

\section{MATERIALS AND METHODS}

This study was prospectively conducted with trauma patients older than 15 years of age who presented to the Dicle University Faculty of Medicine trauma unit in the department of emergency medicine between June I, 2013 and May 3I, 2014. It was approved by the Dicle University medical faculty ethics committee for non-interventional studies. Motor vehicle accidents and falls from a height were included in the HET category, while simple falls (e.g., fall while walking) were considered LET. ${ }^{[7]}$ Firearm injuries, sharp object injuries, simple cuts as a result of assault or accident, and patients younger than 15 years of age were excluded.

BMI $\left(\mathrm{kg} / \mathrm{m}^{2}\right)$ values were calculated for all patients; those with insufficient weight and height information were excluded. Participants were clustered into 4 groups according to BMI value: Group I: BMI <25 (normal-weight), Group II: BMI 25-29.9 (overweight), Group III: BMI 30-34.9 (obese), and Group IV: $\mathrm{BMI} \geq 35$ (morbidly obese). Demographic characteristics at admission (age, sex, trauma mode, weight, height, chronic disorders, Glasgow Coma Scale (GCS), blood pressure, pulse rate, respiratory rate, injury sites, and ISS score), length of stay in intensive care unit (ICU), therapies applied on hospital admission, discharge reports, and death reports were recorded.

Outcomes were compared between BMI groups among HET patients, LET patients, and all trauma patients.

\section{Statistical Analysis}

Data were analyzed with SPSS statistical software (version 18.0; SPSS Inc., Chicago, IL, USA). Data are presented as mean $\pm S D$ for continuous variables and as percentage for categorical variables. Data were compared across the $4 \mathrm{BMI}$ groups using chi-square test for categorical variables and analysis of variance (ANOVA) for continuous variables. For univariate analysis, means of continuous variables among BMI groups were compared using multi-group ANOVA with Bonferroni method used for post hoc analysis. $P$ value of $<0.05$ was considered a statistically significant result. Mortality, hospital admission rate, ICU admission rate, frequency of injury by body region, length of ICU stay, and ISS scores were provided using cross tables. To assess impact of BMI on outcome, multivariate logistic regression analysis was performed with hospital mortality as target variable. Odds ratios with $95 \%$ confidence intervals are reported.

\section{RESULTS}

During the I-year period of study, a total of 4328 trauma patients presented to the emergency service trauma unit. Of these, 1588 patients with HET and LET formed the study group, and 1398 of those patients had the necessary height and weight data and met the study criteria. Mean BMI of whole patient population was $26.49 \pm 4.33$ (range: 19-43). In the entire patient population, $42.2 \%(n=591)$ were normoweight, $36.7 \%(n=513)$ were overweight, $17.1 \%(n=240)$ were obese, and $3.8 \%(n=54)$ were morbidly obese. The number of male patients was $840(60.1 \%)$, and mean age of the whole patient population was 38.09 \pm 18.61 years (range: 15-91 years). Men had a mean age of $35.76 \pm 17.85$ years, and women had a mean age of $41.61 \pm 19.30$ years.

Patients were studied in 2 groups based on trauma severity: HET and LET. Among the study population, 65.4\% $(n=915)$ were subjected to HET, and $34.6 \%(n=483)$ to LET. Of the patients who experienced HET, $41.3 \%(n=378)$ were normoweight, $39.7 \%(n=363)$ were overweight, $14.4 \%(n=132)$ were obese, and $4.5 \%(n=42)$ were morbidly obese. Of the patients who were exposed to LET, $44.1 \%(n=213)$ were normoweight, $31.1 \%(n=150)$ were overweight, $22.3 \%(n=108)$ were obese, and $2.5 \%(n=12)$ were morbidly obese. Comparison of male:female ratio between groups revealed that while male gender predominated in normoweight and overweight patients, female gender predominated in obese patients. There were an equal number of men and women in the morbidly obese group.

Analysis of the whole patient population for inter-group differences in rates of injury by body region showed significant differences in frequency of head injury, thoracic injury, extremity injury, and multitrauma $(p<0.001)$. No significant difference was observed between groups in terms of abdominal injury rate $(p=0.347)$. Additionally, analysis of results indicated a significant difference between groups with respect to clinic admission rate and mortality rate $(p<0.00 \mathrm{I})$, whereas no significant difference was observed in terms of ICU admission rate $(p=0.052)$ (Table $I)$.

Data on inter-group differences in length of ICU stay and ISS scores showed significant differences between mean ISS scores and length of ICU stay (days) of the entire patient population compared to HET and LET groups $(p<0.001)$ (Table 2).

When all patients were analyzed as a whole, it was observed that clinic admission rate, length of ICU stay, mortality rate, multitrauma rate, and ISS score increased in proportion to increase in BMI (Table 3). Clinic admission rate was significantly lower in Group I compared to Groups II, III, and IV ( $<<0.00$ I). Length of ICU stay and mortality rate were higher in both Group III and Group IV (obese groups) compared to both Group I and Group II. ISS scores were higher in Group II, III, and IV than Group I. In the comparison of groups in terms of injury region, no significant difference was observed with respect to the rate of abdominal trauma, although Group IV had a striking increase in trauma rates in all body regions, par- 
Table I. Inter-group differences in type of injury. clinic and intensive care admission rate, and mortality rate

\begin{tabular}{|c|c|c|c|c|c|c|c|c|c|}
\hline & \multicolumn{2}{|c|}{ Group I } & \multicolumn{2}{|c|}{ Group II } & \multicolumn{2}{|c|}{ Group III } & \multicolumn{2}{|c|}{ Group IV } & \multirow[t]{2}{*}{$\mathbf{p}$} \\
\hline & $\mathbf{n}$ & $\%$ & $\mathbf{n}$ & $\%$ & $\mathbf{n}$ & $\%$ & $\mathbf{n}$ & $\%$ & \\
\hline Head injury & 291 & 49.2 & 249 & 48.5 & 105 & 43.6 & 39 & 72.2 & $<0.001$ \\
\hline Thoracic injury & 126 & 21.3 & 93 & 18.1 & 66 & 27.4 & 21 & 38.9 & $<0.001$ \\
\hline Abdominal injury & 45 & 7.6 & 33 & 6.4 & 24 & 10 & 3 & 5.6 & 0.347 \\
\hline Extremity injury & 363 & 61.4 & 270 & 52.6 & 163 & 67.6 & 36 & 66.7 & $<0.001$ \\
\hline Multitrauma & $=192$ & 33 & $=177$ & 34.5 & $=114$ & 47.5 & $=33$ & 61.1 & $<0.001$ \\
\hline Clinical admission & $=153$ & 25.9 & $=207$ & 40.4 & $=99$ & 41.2 & $=27$ & 50 & $<0.001$ \\
\hline ICU admission & $=69$ & 11.7 & $=78$ & 15.2 & $=45$ & 18.8 & $=9$ & 16.7 & 0.052 \\
\hline Mortality & $=6$ & 1 & $=12$ & 2.3 & $=9$ & 3.8 & $=6$ & II.I & $<0.001$ \\
\hline
\end{tabular}

ICU: Intensive care unit;

Table 2. Mean injury severity score and length of intensive care unit stay by group

\begin{tabular}{|c|c|c|c|c|c|}
\hline & Group I & Group II & Group III & Group IV & $\mathbf{p}$ \\
\hline & Mean $\pm S D$ & Mean $\pm S D$ & Mean $\pm S D$ & Mean \pm SD & \\
\hline All patients' mean ISS scores & $9.46 \pm 11.93$ & $14.93 \pm 14.46$ & $59 \pm 14.73$ & $16.22 \pm 9.51$ & $<0.001$ \\
\hline All patients' length of ICU stay & $3.84 \pm 2.98$ & $6.12 \pm 4.78$ & $10.98 \pm 9.98$ & $13.22 \pm 7.36$ & $<0.001$ \\
\hline HET patients' mean ISS score & $12.63 \pm 13.60$ & $|8.97 \pm| 5.2 \mid$ & $25.52 \pm 14.66$ & $19.29 \pm 8.47$ & $<0.001$ \\
\hline LET patients' mean ISS scores & $3.82 \pm 4.19$ & $5.16 \pm 4.61$ & $7.89 \pm 7.02$ & $5.50 \pm 2.71$ & $<0.001$ \\
\hline
\end{tabular}

HET: High-energy trauma; ICU: Intensive care unit; ISS: Injury severity score; LET: Low-energy trauma; SD: Standard deviation.

ticularly the multitrauma rate. Head trauma was more common in Group IV than the other groups; it was more frequent particularly in Group III and Group IV, the obese groups, compared to Group I. Thoracic trauma was more common in Group III and Group IV than in Group I and Group II. No significant difference was observed between groups with regard to rate of abdominal trauma. The rate of extremity trauma was higher in Groups I, III, and IV than in Group II. The multitrauma rate increased as $\mathrm{BMI}$ increased, and it was higher in the obese groups., i.e., Group III and Group IV, than in Group I and Group II.

Analysis of only patients presenting with HET revealed greater length of ICU stay, mortality rate, ISS score, and multitrauma rate in proportion to increase in BMI (Table 4). The clinic admission rate was higher in Groups II and IV than in Group I, and higher in Group IV than in Group III. Length of ICU stay was greater in Group III and Group IV (the obese groups) than in Group I and Group II. Mortality rate, as was length of ICU stay, was higher in Group III and Group IV than in Group I and Group II. Furthermore, mortality rates of Group II, Group III, and Group IV were higher than that of Group I, and mortality rate of Group IV was higher than that of Group III. ISS scores were significantly higher in Group II, Group III, and Group IV than those of Group I. In addition, ISS score of
Group III was higher than that of Group II. Comparison of groups with respect to injury regions revealed no significant difference with regard to rate of abdominal trauma, while the rate of head trauma was markedly higher in Group IV than the other groups. Rate of thoracic trauma and multitrauma rate were significantly higher in Group III and Group IV than in Group I and Group II. The rate of extremity injury was higher in Group III and Group I than in Group II.

When only patients presenting with LET were analyzed, it was noted that no patient was admitted to ICU. While no mortality was observed in Group I, Group III, or Group IV, 2 patients in Group II died in the emergency service due to severe head trauma. In addition, clinic admission rate and ISS score increased in proportion to BMI increase in groups other than Group IV. Comparison of groups by injury region was only performed between Group I, Group II, and Group III for injury regions other than extremities because 12 patients in Group IV only had extremity trauma. Although rate of head trauma was higher in Group I than in Group II and Group III, only the difference found in Group II was statistically significant. No significant difference existed between groups with respect to rate of thoracic trauma. Since no abdominal trauma existed in Group I or Group IV, a statistical comparison could not be done. Rate of extremity trauma was higher in 
Table 3. Analysis of body mass index groups in the whole patient population with respect to injury severity score and injury region

\begin{tabular}{|c|c|c|c|}
\hline \multirow{2}{*}{$\begin{array}{l}\text { Parameters } \\
\text { Clinical admission, \% (n) }\end{array}$} & \multicolumn{2}{|c|}{ Groups } & \multirow{2}{*}{$\begin{array}{c}\mathbf{p} \\
<0.00\end{array}$} \\
\hline & Group | 25.9 (153) & Group II 40.4 (207) & \\
\hline & & Group III 41.2 (99) & $<0.001$ \\
\hline & & Group IV 50 (27) & $<0.001$ \\
\hline & Group II 40.4 (207) & Group III 41.2 (99) & 0.812 \\
\hline & & Group IV 50 (27) & 0.192 \\
\hline & Group III 41.2 (99) & Group IV 50 (27) & 0.287 \\
\hline Length of intensive care unit stay & Group | 3.84 \pm 2.98 & Group II $6.12 \pm 4.78$ & 0.143 \\
\hline \multirow[t]{5}{*}{ (days; Mean \pm SD) } & & Group III I0.98 \pm 9.98 & $<0.001$ \\
\hline & & Group IV $13.22 \pm 7.36$ & $<0.001$ \\
\hline & Group II $6.12 \pm 4.78$ & Group III 10.98 \pm 9.98 & $<0.001$ \\
\hline & & Group IV 13.22 \pm 7.36 & 0.006 \\
\hline & 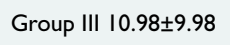 & Group IV $13.22 \pm 7.36$ & 1.000 \\
\hline \multirow[t]{6}{*}{ Mortality, \% (n) } & Group I I (6) & Group II 2.3 (12) & 0.067 \\
\hline & & Group III 3.8 (9) & 0.017 \\
\hline & & Group IV II.I (6) & 0.001 \\
\hline & Group II 2.3 (I2) & Group III 3.8 (9) & 0.341 \\
\hline & & Group IV II.I (6) & 0.004 \\
\hline & Group III $3.8(9)$ & Group IV II.I (6) & 0.038 \\
\hline \multirow[t]{6}{*}{ Injury severity score (Mean \pm SD) } & Group | $9.46 \pm 11.93$ & Group II $14.93 \pm 14.46$ & 0.001 \\
\hline & & Group III 59 14.73 & 0.001 \\
\hline & & Group IV 16.22 \pm 9.51 & 0.002 \\
\hline & 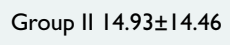 & Group III 59 14.73 & 0.066 \\
\hline & & Group IV 16.22 \pm 9.51 & 1.000 \\
\hline & Group III 59 \pm 14.73 & Group IV 16.22 99.51 & 0.100 \\
\hline \multirow[t]{6}{*}{ Head injury, \% (n) } & Group | 49.2 (291) & Group II 48.5 (249) & 0.816 \\
\hline & & Group III 43.6 (105) & 0.150 \\
\hline & & Group IV 72.2 (39) & 0.001 \\
\hline & Group II 48.5 (249) & Group III 43.6 (105) & 0.220 \\
\hline & & Group IV 72.2 (39) & 0.001 \\
\hline & Group III 43.6 (105) & Group IV 72.2 (39) & $<0.001$ \\
\hline \multirow[t]{6}{*}{ Thoracic injury, \% (n) } & Group | 21.3 (126) & Group II I8.I (93) & 0.185 \\
\hline & & Group III 27.4 (66) & 0.084 \\
\hline & & Group IV 38.9 (2I) & 0.003 \\
\hline & Group II I8.I (93) & Group III 27.4 (66) & 0.003 \\
\hline & & Group IV 38.9 (2I) & 0.001 \\
\hline & Group III 27.4 (66) & Group IV 38.9 (2I) & 0.098 \\
\hline \multirow[t]{6}{*}{ Abdominal injury, \% (n) } & Group I 7.6 (45) & Group II 6.4 (33) & 0.445 \\
\hline & & Group III I0 (24) & 0.229 \\
\hline & & Group IV 5.6 (3) & 0.581 \\
\hline & Group II 6.4 (33) & Group III I0 (24) & 0.085 \\
\hline & & Group IV 5.6 (3) & 1.000 \\
\hline & Group III I0 (24) & Group IV 5.6 (3) & 0.307 \\
\hline \multirow[t]{6}{*}{ Extremity injury, \% (n) } & Group | 61.4 (363) & Group II 52.6 (270) & 0.003 \\
\hline & & Group III 67.6 (I63) & 0.308 \\
\hline & & Group IV 66.7 (36) & 0.447 \\
\hline & Group II 52.6 (270) & Group III 67.6 (163) & 0.001 \\
\hline & & Group IV 66.7 (36) & 0.049 \\
\hline & Group III 67.6 (163) & Group IV 66.7 (36) & 0.906 \\
\hline \multirow[t]{6}{*}{ Multitrauma, \% (n) } & Group I 33 (192) & Group II 34.5 ( (177) & 0.479 \\
\hline & & Group III 47.5 (1 I4) & 0.001 \\
\hline & & Group IV 61.1 (33) & 0.001 \\
\hline & Group II 34.5 (177) & Group III 47.5 (114) & 0.001 \\
\hline & & Group IV 6I.I (33) & 0.001 \\
\hline & Group III 47.5 (II4) & Group IV 61.1 (33) & 0.071 \\
\hline
\end{tabular}


Table 4. Analysis of body mass index groups in terms of prognosis, injury severity score, and injury region among patients who were exposed to high-energy trauma

\begin{tabular}{|c|c|c|c|}
\hline \multirow{2}{*}{$\begin{array}{l}\text { Parameters } \\
\text { Clinical admission, \% (n) }\end{array}$} & \multicolumn{2}{|c|}{ Groups } & \multirow{2}{*}{$\begin{array}{c}\mathbf{p} \\
<0.001\end{array}$} \\
\hline & Group I 28.6 ( 108$)$ & Group II 43 (I56) & \\
\hline & & Group III 36.4 (48) & 0.094 \\
\hline & & Group IV 57. I (24) & $<0.001$ \\
\hline & Group II 43.0 (156) & Group III 36.4 (48) & 0.186 \\
\hline & & Group IV 57. I (24) & 0.080 \\
\hline & Group III 36.4 (48) & Group IV 57. I (24) & 0.017 \\
\hline Length of intensive care unit stay & 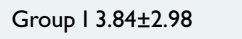 & Group II $6.12 \pm 4.78$ & 0.143 \\
\hline \multirow[t]{5}{*}{ (days; Mean $\pm S D$ ) } & & Group III I0.98 \pm 9.98 & $<0.001$ \\
\hline & & Group IV $13.22 \pm 7.36$ & $<0.001$ \\
\hline & Group II $6.12 \pm 4.78$ & Group III 10.98 \pm 9.98 & $<0.001$ \\
\hline & & Group IV $13.22 \pm 7.36$ & 0.006 \\
\hline & 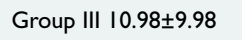 & Group IV $13.22 \pm 7.36$ & 1.000 \\
\hline \multirow[t]{6}{*}{ Mortality, \% (n) } & Group I I.6 (6) & Group II 2.5 (9) & 0.389 \\
\hline & & Group III 6.8 (9) & 0.002 \\
\hline & & Group IV I4.3 (6) & $<0.001$ \\
\hline & Group II 2.5 (9) & Group III 6.8 (9) & 0.023 \\
\hline & & Group IV I4.3 (6) & $<0.001$ \\
\hline & Group III 6.8 (9) & Group IV I4.3 (6) & 0.133 \\
\hline \multirow[t]{6}{*}{ Injury severity score (Mean $\pm S D$ ) } & Group I I2.63 \pm 13.60 & 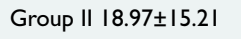 & $<0.001$ \\
\hline & & Group III $25.52 \pm 14.66$ & $<0.001$ \\
\hline & & Group IV 19.29 \pm 8.47 & 0.025 \\
\hline & 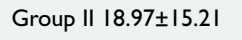 & Group III $25.52 \pm 14.66$ & $<0.001$ \\
\hline & & Group IV 19.29 \pm 8.47 & 1.000 \\
\hline & Group III $25.52 \pm 14.66$ & Group IV 19.29 \pm 8.47 & 0.081 \\
\hline \multirow[t]{6}{*}{ Head injury, \% (n) } & Group I 55.6 (210) & Group II 58.7 (2|3) & 0.391 \\
\hline & & Group III 52.3 (69) & 0.514 \\
\hline & & Group IV 92.9 (39) & $<0.001$ \\
\hline & Group II 58.7 (2|3) & Group III 52.3 (69) & 0.203 \\
\hline & & Group IV 92.9 (39) & $<0.001$ \\
\hline & Group III 52.3 (69) & Group IV 92.9 (39) & $<0.001$ \\
\hline \multirow[t]{6}{*}{ Thoracic injury, \% (n) } & Group | 30.2 (114) & Group II 24.8 (90) & 0.102 \\
\hline & & Group III 47.7 (63) & $<0.001$ \\
\hline & & Group IV 50 (2I) & 0.009 \\
\hline & Group II $24.8(90)$ & Group III 47.7 (63) & $<0.001$ \\
\hline & & Group IV 50 (2I) & 0.001 \\
\hline & Group III 47.7 (63) & Group IV 50 (2I) & 0.797 \\
\hline \multirow[t]{6}{*}{ Abdominal injury, \% (n) } & Group I I I.9 (45) & Group II 8.3 (30) & 0.101 \\
\hline & & Group III 8.3 (30) & 0.603 \\
\hline & & Group IV 7.1 (3) & 0.357 \\
\hline & Group II 8.3 (30) & Group III 8.3 (30) & 0.074 \\
\hline & & Group IV 7.1 (3) & 0.801 \\
\hline & Group III 8.3 (30) & Group IV 7.1 (3) & 0.261 \\
\hline \multirow[t]{6}{*}{ Extremity injury, \% (n) } & Group I 62.7 (237) & Group II 46.3 (168) & $<0.001$ \\
\hline & & Group III 6I.4 (8I) & 0.785 \\
\hline & & Group IV 57.1 (24) & $0.48 I$ \\
\hline & Group II 46.3 (168) & Group III 61.4 (8I) & 0.003 \\
\hline & & Group IV $57 . I$ (24) & 0.182 \\
\hline & Group III 6I.4 (8I) & Group IV 57.1 (24) & 0.626 \\
\hline \multirow[t]{6}{*}{ Multitrauma, \% (n) } & Group | 46.8 (I77) & Group II $47 . I$ (I7I) & 0.939 \\
\hline & & Group III 72.7 (96) & $<0.001$ \\
\hline & & Group IV 78.6 (33) & $<0.001$ \\
\hline & Group II 47.1 (17I) & Group III 72.7 (96) & $<0.001$ \\
\hline & & Group IV 78.6 (33) & $<0.001$ \\
\hline & Group III 72.7 (96) & Group IV 78.6 (33) & 0.451 \\
\hline
\end{tabular}


Table 5. Analysis of body mass index groups with respect to prognosis, injury severity score, and injury region among patients who were exposed to low-energy trauma

\begin{tabular}{|c|c|c|c|}
\hline \multirow{2}{*}{$\begin{array}{l}\text { Parameters } \\
\text { Clinical admission, \% (n) }\end{array}$} & \multicolumn{2}{|c|}{ Groups } & \multirow{2}{*}{$\begin{array}{c}\mathbf{p} \\
0.006\end{array}$} \\
\hline & Group I 2 I.I (45) & Group II 34 (5I) & \\
\hline & & Group III $47.2(5 \mathrm{I})$ & $<0.001$ \\
\hline & & Group IV 25 (3) & 0.750 \\
\hline & Group II 34 (5I) & Group III $47.2(5 \mathrm{I})$ & 0.032 \\
\hline & & Group IV 25 (3) & 0.525 \\
\hline & Group III 47.2 (5I) & Group IV 25 (3) & 0.142 \\
\hline \multirow[t]{6}{*}{ Mortality, \% (n) } & Group $10(0)$ & Group II 2 (3) & 0.038 \\
\hline & & Group III $0(0)$ & - \\
\hline & & Group IV $0(0)$ & - \\
\hline & Group II 2 (3) & Group III $0(0)$ & 0.139 \\
\hline & & Group IV $0(0)$ & 0.621 \\
\hline & Group III $0(0)$ & Group IV $0(0)$ & - \\
\hline \multirow[t]{6}{*}{ Injury severity score (Mean $\pm S D$ ) } & Group | 3.82 \pm 4.19 & Group II $5.16 \pm 4.61$ & 0.081 \\
\hline & & Group III 7.89 7.02 & $<0.001$ \\
\hline & & Group IV $5.50 \pm 2.7$ I & 1.000 \\
\hline & Group II $5.16 \pm 4.6 \mid$ & Group III 7.89 7.02 & $<0.001$ \\
\hline & & Group IV $5.50 \pm 2.7$ I & 1.000 \\
\hline & Group III 7.89 7.02 & Group IV $5.50 \pm 2.71$ & 0.730 \\
\hline \multirow[t]{6}{*}{ Head injury, \% (n) } & Group I 38 (8I) & Group II 24 (36) & 0.005 \\
\hline & & Group III 33.3 (36) & 0.409 \\
\hline & & Group IV $0(0)$ & 0.008 \\
\hline & Group II 24 (36) & Group III 33.3 (36) & 0.099 \\
\hline & & Group IV $0(0)$ & 0.054 \\
\hline & Group III 33.3 (36) & Group IV $0(0)$ & 0.017 \\
\hline \multirow[t]{6}{*}{ Thoracic injur, \% (n) } & Group I 5.6 (I2) & Group II 2 (3) & 0.087 \\
\hline & & Group III 2.8 (3) & 0.252 \\
\hline & & Group IV 0 (0) & 0.398 \\
\hline & Group II $2(n=3)$ & Group III 2.8 (3) & 0.683 \\
\hline & & Group IV 0 (0) & 0.621 \\
\hline & Group III 2.8 (3) & Group IV 0 (0) & 0.559 \\
\hline \multirow[t]{6}{*}{ Abdominal injury, \% (n) } & Group I 0 (0) & Group II 2 (3) & 0.038 \\
\hline & & Group III 5.6 (6) & 0.001 \\
\hline & & Group IV 0 (0) & - \\
\hline & Group II 2 (3) & Group III 5.6 (6) & 0.125 \\
\hline & & Group IV 0 (0) & 0.621 \\
\hline & Group III 5.6 (6) & Group IV 0 (0) & 0.402 \\
\hline \multirow[t]{6}{*}{ Extremity injury, \% (n) } & Group I 59 (126) & Group II 68 (102) & 0.086 \\
\hline & & Group III 75 (8I) & 0.005 \\
\hline & & Group IV 100 (I2) & 0.005 \\
\hline & Group II 68 (102) & Group III 75 (8I) & 0.222 \\
\hline & & Group IV 100 (12) & 0.019 \\
\hline & Group III 75 (8I) & Group IV 100 (12) & 0.049 \\
\hline \multirow[t]{6}{*}{ Multitrauma, \% (n) } & Group I 7 (I5) & Group II 4 (6) & 0.222 \\
\hline & & Group III I6.7 (18) & 0.007 \\
\hline & & Group IV 0 (0) & 0.341 \\
\hline & Group II 4 (6) & Group III I6.7 (I8) & 0.001 \\
\hline & & Group IV 0 (0) & 0.480 \\
\hline & Group III I6.7 (I8) & Group IV 0 (0) & 0.125 \\
\hline
\end{tabular}

Group III and Group IV than in Group I, and higher in Group IV than in Groups I, II, and III (Table 5).

In the prediction of death, multiple logistic regression mod- els revealed that overweight, obese, and morbidly obese patients have increased odds of death. It was also seen that mortality rate increased in parallel with increasing BMI values (Table 6). 
Table 6. Logistic regression analysis of body mass index groups with respect to exitus

\begin{tabular}{lccc}
\hline Groups & Exp (B) & $95 \%$ CI for EXP (B) & Significant \\
\hline Group I & 9.377 & $4.514-19.480$ & $<0.001$ \\
Group II & 21.898 & $10.541-45.492$ & $<0.001$ \\
Group III & 35.620 & $17.146-73.999$ & $<0.001$ \\
Group IV & 114.280 & $55.009-237.413$ & $<0.001$ \\
\hline
\end{tabular}

$\mathrm{Cl}$ : Confidence interval.

\section{DISCUSSION}

Trauma-induced injuries are among the most common reasons for emergency service admission. Multitrauma is usually seen in young people and male gender. ${ }^{[8]}$ In a study on patients with blunt multitrauma, Altuncı et al. reported male:female ratio of 5:2. ${ }^{[9]}$ According to 2012 statistics of Turkish Statistical Institute (TÜiK), 17.2\% of the population aged 15 years or older was obese, $34.8 \%$ were overweight, $44.2 \%$ were normoweight, and $3.9 \%$ were underweight. According to these data, $52 \%$ of the Turkish population is above normal weight. The analysis of the available data in terms of gender revealed that $20.9 \%$ of Turkish women are obese and $30.4 \%$ are overweight, while $13.7 \%$ of men are obese and $39 \%$ are overweight. The predominance of female gender among obese persons is particularly striking. ${ }^{[10]}$ In the present study, the male:female ratio was 3:2 in the whole study population. When analyzed by BMI, there was female gender predominance among obese persons and male predominance in the categories of overweight and normoweight, corresponding to TÜiK data. Among morbidly obese patients, number of men and women was equal, probably due to a limited sample size. When obese and morbidly obese patients were analyzed together, however, the ratio was in agreement with the literature data. This difference between overweight and obese patients may originate from higher rate of obesity among women due to the fact that majority of women living in our region are housewives, have a high fertility rate, have a tendency for obesity, and are less active than men in their daily lives.

Studies investigating the cause and effect relationship between trauma and obesity have observed that obesity increased mortality and morbidity rates independently of injury severity when obese persons were exposed to severe blunt trauma. ${ }^{[1-13]}$ Xiang et al. called attention to high injury risk in persons older than 18 years of age who had BMI $\geq 35$. $^{[14]}$ Smith-Choban et al. showed that in patients who were exposed to blunt trauma, mortality rate was higher in patients having $\mathrm{BMI}>3 \mathrm{I}$ than in normoweight subjects, mortality rate increased in proportion to $\mathrm{BMI}$ increase, and that $\mathrm{BMI}$ was a poor prognostic factor in trauma. ${ }^{[15]}$ In the 2012 TÜiK data, analysis of deaths occurring within I year $(n=320967)$ demonstrated that rate of death from traffic accidents and falls was $2.12 \%$ (6820), and male:female ratio was approximately $2: 1 .{ }^{[6]}$ In the present study, male:female ratio was $2: I$, similar to that reported by TÜiK. In addition, similar to previous reports, mortality rate, clinic admission rate, ICU admission rate, and ISS increased in parallel with BMI increase, with mortality rate in first place. This increase, especially in morbid obesity, is the most striking aspect of the present study. In the opinion of the authors, this occurred because obese persons are exposed to greater force due to their greater weight, and thus sustain more severe injuries than normoweight persons in crash injuries. Furthermore, high incidence of comorbid conditions accompanying obesity such as DM, insulin resistance, chronic obstructive pulmonary disease, hypertension, hyperlipidemia, coronary artery disease, and other vascular diseases, as well as lower physiological reserve in obese persons may contribute to deterioration of general condition of these patients. ${ }^{[1]]}$

Studies investigating the poor prognostic impact of obesity in trauma cases showed that head trauma was less common and extremity trauma was more common in obese persons than normoweight persons. ${ }^{[6,17,18]}$ It has been demonstrated that rate of extremity injury was higher and rate of abdominal injury was lower. ${ }^{[6]}$ Boulanger et al. demonstrated that rates of thoracic, lower extremity, and pelvic injuries were higher, and rate of head trauma was lower in obese persons who were exposed to HET. The authors explained higher rate of lower extremity fractures in HET with increased burden on lower extremities of greater body mass. ${ }^{[18]}$ Arbabi et al. found high rate of lower extremity fracture in motor vehicle accidents, ${ }^{[19]}$ and Gabriel et al. showed an increased rate of extremity trauma in overweight persons suffering motor vehicle accidents. ${ }^{[17]}$ The present study had results similar in many aspects to those of previous studies. Finding of higher rate of injuries involving all regions except head in obese and morbid obese patients was compatible with previous literature findings. However, similar rates of head trauma in patient groups except morbidly obese group, which had a significantly higher rate, contradicts previous reports. We think that this difference in the present study originated as a result of smaller number of morbidly obese patients than other patients. The finding of higher rates of extremity trauma, thoracic trauma, and especially multitrauma in obese and morbidly obese patients compared to normoweight and overweight patients supports the findings of earlier studies.

Another noteworthy point in the present study was that clinic admission rate, length of ICU stay, and ISS score were significantly greater in obese and morbidly obese patients than normoweight and overweight patients, and they increased in proportion to BMI increase when patients who experienced HET were analyzed separately. Clinic admission rate, mortality rate, and length of ICU stay were significantly higher in morbidly obese group than in other groups. Although the finding of higher rate of head trauma in morbidly obese patients compared to other groups contradicted literature data, higher 
rates of thoracic trauma and multitrauma were in agreement with the literature. We think that this disagreement in head trauma data was due to fact that traffic accidents are more common among HET patients, and there is a lack of awareness and appreciation about the need to take safety measures such as fastening seat belt that originates in the socioeconomic level of our region. The results indicated that increased $\mathrm{BMI}$ was a poor prognostic factor in cases of HET.

It was observed that rate of extremity trauma increased in proportion to BMI increase. All morbidly obese patients who presented with LET such as simple falls only had extremity trauma. This can be explained by excessive burden of increased body mass upon extremities as BMI increases. and the difficulty that these patients experience in balanced walking.

\section{Conclusion}

Obesity increases mortality and morbidity independently of injury severity in trauma patients. As BMI increased, length of hospital stay, rate and length of ICU stay, rate of extremity injury, multitrauma, and death also increased. Serious extremity traumas can be seen even in instances of LET in obese patients, and this is particularly true for the morbidly obese.

Conflict of interest: None declared.

\section{REFERENCES}

1. Calle EE, Thun MJ, Petrelli JM, Rodriguez C, Heath CW Jr. Body-mass index and mortality in a prospective cohort of U.S. adults. N Engl J Med 1999;341:1097-105. Crossref

2. National Institutes of Health. Clinical Guidelines on the Identification, Evaluation, and Treatment of Overweight and Obesity in Adults: the Evidence Report. Washington, DC: National Institutes of Health Publication; 1998. p. 98-4083.

3. WISQARS Leading Causes of Death Reports, 1999-2003. Atlanta: Centers for Disease Control and Prevention, National Center for Injury Prevention and Control; 2006. Available at: http://webappa.cdc.gov/sasweb/ncipc/leadcaus10.html. Accessed on: August 8, 2006.

4. Ciesla DJ, Moore EE, Johnson JL, Burch JM, Cothren CC, Sauaia A. Obesity increases risk of organ failure after severe trauma.J Am Coll Surg 2006;203:539-45. Crossref

5. Ryb GE, Dischinger PC. Injury severity and outcome of overweight and obese patients after vehicular trauma: a crash injury research and engineering network (CIREN) study. J Trauma 2008;64:406-11. Crossref

6. Brown CV, Neville AL, Salim A, Rhee P, Cologne K, Demetriades D. The impact of obesity on severely injured children and adolescents. J Pediatr Surg 2006;41:88-91. Crossref

7. Lee WT, Murphy D, Kagda FH, Thambiah J. Proximal femoral locking compression plate for proximal femoral fractures. J Orthop Surg (Hong Kong) 2014;22:287-93.

8. Dur A, Cander B, Kocak S, Girisgin S, Gul M, Koyuncu F. Multitrauma patients and trauma scoring systems in emergency-intensive care unit. J Acad Emerg Med 2009;8:24-7.

9. Altunc1 Y, Aldemir M, Guloglu C, Ustundag M, Guloglu C. The effective factors in emergency department observation on hospitalization requirement and mortality in blunt trauma patients. J Acad Emerg Med 2010;9:117-20.

10. Turkish Statistical Institute. Turkey Health Survey, 2012, April 2013. Available at: http://www.turkstat.gov.tr/PreHaberBultenleri. do?id=13490. Accessed on: December 25, 2014.

11. Neville AL, Brown CV, Weng J, Demetriades D, Velmahos GC. Obesity is an independent risk factor of mortality in severely injured blunt trauma patients. Arch Surg 2004;139(9):983-7. Crossref

12. Maheshwari R, Mack CD, Kaufman RP, Francis DO, Bulger EM, Nork SE, et al. Severity of injury and outcomes among obese trauma patients with fractures of the femur and tibia: a crash injury research and engineering network study. J Orthop Trauma 2009;23:634-9. Crossref

13. Hoffmann M, Lefering R, Gruber-Rathmann M, Rueger JM, Lehmann W. Trauma Registry of the German Society for Trauma Surgery. The Impact of BMI on Polytrauma Outcome. Injury 2012;43:184-8. Crossref

14. Xiang H, Smith GA, Wilkins JR 3rd, Chen G, Hostetler SG, Stallones L. Obesity and risk of nonfatal unintentional injuries. Am J Prev Med 2005;29:41-5. Crossref

15. Choban PS, Weireter LJ Jr, Maynes C. Obesity and increased mortality in blunt trauma. J Trauma 1991;31:1253-7. Crossref

16. Turkish Statistical Institute. Causes of Death Statistics, 2010, 2011 and 2012, April 2013. Available at: http://www.turkstat.gov.tr/PreHaberBultenleri.do?id=15847. Accessed on: December 25, 2014.

17. Ryb GE, Dischinger PC. Injury severity and outcome of overweight and obese patients after vehicular trauma: a crash injury research and engineering network (CIREN) study. J Trauma 2008;64:406-11. Crossref

18. Boulanger BR, Milzman D, Mitchell K, Rodriguez A. Body habitus as a predictor of injury pattern after blunt trauma. J Trauma 1992;33:22832. Crossref

19. Arbabi S, Wahl WL, Hemmila MR, Kohoyda-Inglis C, Taheri PA, Wang SC. The cushion effect. J Trauma 2003;54:1090-3. Crossref 
ORİIINAL ÇALIŞMA - ÖZET

\section{Travma hastalarında vücut kitle indeksinin travma şiddeti ve prognoza etkisi \\ Dr. Hasan Mansur Durgun, ${ }^{1}$ Dr. Recep Dursun, ${ }^{1}$ Dr. Yılmaz Zengin, ${ }^{1}$ Dr. Ayhan Özhasenekler, ${ }^{2}$ Dr. Murat Orak, ${ }^{1}$ Dr. Mehmet Üstündağ, ${ }^{1}$ Dr. Cahfer Güloğlư ${ }^{1}$}

${ }^{1}$ Dicle Üniversitesi Tıp Fakültesi, Acil Tıp Anabilim Dalı, Diyarbakır

${ }^{2}$ Yıldırım Beyazıt Üniversitesi Tıp Fakültesi, Acil Tıp Anabilim Dalı, Ankara

AMAÇ: Son yıllarda tüm dünyada olduğu gibi Türkiye'de de obezite çok ciddi bir toplum sorunu olacak şekilde giderek artmaktadır. Bugüne kadar obezitenin dahili hastalıklarıyla ilgili birçok çalışma yapılmasına rağmen travma hastalarında obezitenin prognoz üzerindeki etkisini inceleyen çok az çalışma mevcuttur. Bu çalışmada travma hastalarında vücut kitle indeksinin (VKI) travma şiddeti ve prognoz üzerine etkilerini araştırmayı amaçladık. GEREÇ VE YÖNTEM: Bu ileriye yönelik çalışmada 0 I Haziran 2013 ile 3I Mayıs 2014 tarihleri arasında Dicle Üniversitesi Tıp Fakültesi Hastanesi Acil Servisi Travma Ünitesi'ne başvuran 15 yaş üstü travma hastaları incelendi. Hastalar maruz kaldıkları travmanın şiddetine göre yüksek enerjili travma (YET) ve düşük enerjili travma (DET) olmak üzere iki gruba ayrıldı. Hastalar BMI ( $\left.\mathrm{kg} / \mathrm{m}^{2}\right)$ değerlerine göre 4 gruba ayrıldı: Grup I; BMl<25 (normal kilolu grup), Grup II; VKi 25-29.9 (kilo fazlalığı grubu), Grup III; VKi 30-34.9 (obez grup), Grup IV; VKi $\geq 35$ (morbid obez grup).

BULGULAR: Tüm hastaların gruplar arası farkları incelendiğinde gruplar arasında baş yaralanması, toraks yaralanması, ekstremite yaralanması, çoklu travma oranı, klinik yatış oranı ve mortalite açısından belirgin fark saptandı $(p<0.00 \mathrm{I})$. Karın yaralanması açısından gruplar arasında belirgin bir fark görülmedi ( $p=0.347)$.

TARTIŞMA: Travma hastalarında VKI arttıkça klinik yatış oranı, yoğun bakımda yatış süresi, mortalite oranı, multitravma oranı ve ISS skoru artmaktadır.

Anahtar sözcükler: Travma, travma şiddet skoru; vücut kitle indeksi.

Ulus Travma Acil Cerrahi Derg 2016;22(5):457-465 doi: 10.5505/tjtes.2016.93385 